\title{
CONTROL OF NEEDLE-CAST OF DOUGLAS FIR BY ANTIBIOTICS ${ }^{1}$
}

\author{
BY L. C. WEIR
}

L. C. Weir received his degree in Forestry from the University of British Columbia in 1959 and his M.Sc. from Iowa State University in 1961. He joined the staff of the Forest Entomology and Pathology Laboratory, Victoria, B.C., in 1960.

\section{$A B S T R A C T$}

Phyto-actin, Actidione, and chemical derivatives of Actidione were applied as stem sprays and as foliar sprays to Douglas fir trees infected by Rhabdocline pseudotsugae Syd. All materials provided a reduction in infection level although some trees exhibited little response. Phytotoxicity was evidenced by tree mortality and needle loss. Actidione was shown to move systematically in stemtreated Douglas fir.

\section{INTRODUCTION}

Defoliation of Douglas fir (Pseudotsuga menziesii (Mirb.) Franco), caused by Rhabdocline pseudotsugae Syd., recorded first by J. R. Weir (7) in Idaho, has been reported in natural and planted stands throughout North America. Wilson (11) and van Vloten (6) reported it as causing damage in Great Britain and in continental Europe.

None of the few attempts to control the disease in North America has been completely successful. Brandt (1) reviewed control measures, and from his own experiments reported that 5 applications of lime-sulphur or Ferbam gave control, although uneconomic, when applied over a single growing season. The use of antibiotics in the treatment of white pine blister rust (Cronartium ribicola Fischer) and the degree of control with associated phytotoxicity have been reported by Moss (4) and Moss et al (5). Studies by Wicker and Leaphart (10) suggested the possibility of success with their use against Rhabdocline needle-cast.

\section{Materials And Methods}

A total of 365 trees was selected within the confines of an area of needle-cast epidemic at Canal Flats, in British Columbia. The area was cutover annually in a Christmas tree harvest, and the remaining stock averaged 44 years of age. The loss of foliage from annual infections over previous years indicated susceptibility, which, with tree height and isolation from surrounding trees were criteria for the choice of trees for treatment. A tree height of 15 feet was considered to be the maximum to allow complete coverage by foliar sprays and adequate random sampling of foliage.

${ }^{1}$ Contribution No. 918 of the Forest Entomology and Pathology Branch, Department of Forestry, Ottawa, Canada. Based on a Master of Science thesis submitted to Iowa State University, Ames, Iowa, 1961.

${ }^{3}$ Research Officer, Department of Forestry, Forest Entomology and Pathology Branch, Victoria, British Columbia. 
The materials listed in Table 1 were applied in varying concentrations by two methods. The Actidione complement was applied in concentrations of 100,200,

TABLE 1

SPRAY Materials Used IN EXPERIMENTATION

\begin{tabular}{lcl}
\hline \multicolumn{1}{c}{ Materials } & $\begin{array}{c}\text { Formulation } \\
\text { number }\end{array}$ & $\begin{array}{c}\text { Assigned } \\
\text { listing }\end{array}$ \\
\hline Actidione BR concentrate & - & A-BR \\
Actidione 1.28\% solution & 173 & A-s \\
Cycloheximide methyl hydrazone & 174 & C-mh \\
Cycloheximide acetate & 175 & C-a \\
Cycloheximide aceto-acetate & 176 & C-aa \\
Cycloheximide oxime & 177 & C-o \\
Cycloheximide semicarbazone & 178 & C-sc \\
Cycloheximide thiosemicarbazone & 179 & C-tsc \\
& L-317 & \\
Phyto-actin & L-318 & Ph-ac \\
& L-319 & \\
\hline
\end{tabular}

400 , and $800 \mathrm{ppm}$, and Phyto-actin in concentrations of 100, 200, and 400 $\mathrm{ppm}$. The methods of application were foliar sprays with a stove oil-water emulsion carrier, and basal stem sprays using stove oil alone as the carrier. All spraying was done in July, 1960, with a 1-gallon Dobbin hand sprayer. Each combination of concentration and method was applied to 5 trees, giving a total of 350 trees. Controls were obtained by carriers alone applied to 5 trees each, and an additional 5 trees, receiving no treatment, served as checks.

In June, 1961, the control and check trees were sampled by removing 30 randomly selected twigs from each tree. Needle counts were made on the 1960 foliage with respect to missing needles, infected, and total needles per twig, the missing needle data providing an assessment of the needle fall that occurs normally each year from healthy as well as from infected trees. The count data were analyzed to determine variability between control and check trees and to establish a sample size for the experiment. The analysis indicated no statistically significant difference between sets and that 10 twigs per treated tree would provide for the detection of differences of 5 needles or more with a 95 percent probability.

To provide evidence of the translocation of treatment material, an application of $400 \mathrm{ppm}$ of Actidione BR concentrate was made to 5 trees in June, 1961. On each of the first, second, fourth, eighth, and sixteenth day after spraying, one sample tree was felled and a 400-gram sample of needles removed from the middle and from the upper third of the tree. The samples were processed by techniques developed by Whiffen (9) and Lemin et al (3) for use with white pine foliage. Similar treatment of Douglas fir needles created excessive amounts of non-essential residue. The differential 
solubility of Actidione and residue in reagent-grade acetone perimtted some purification of the extract which was then used in paper chromatography and bioassay.

\section{RESULTS}

Evaluation of the effects of the spray materials was made in terms of tree reaction and disease reaction. The similarity between control and check trees justified their combination giving control tree values based on a total of 15 trees. The reaction of treated trees was measured in terms of tree mortality and needle loss. Tree mortality values (Table 2), given in

TABLE 2

Tree Mortality Following Spray Application

\begin{tabular}{|c|c|c|c|c|c|c|c|c|c|c|c|}
\hline \multirow[b]{2}{*}{$\begin{array}{c}\text { Spray } \\
\text { material }\end{array}$} & \multirow[b]{2}{*}{$\begin{array}{c}\text { Conc. } \\
(\mathbf{p p m}) \\
0\end{array}$} & \multicolumn{8}{|c|}{ Number of trees } & \multicolumn{2}{|c|}{$\begin{array}{c}\text { Percentage } \\
\text { of trees }\end{array}$} \\
\hline & & $\begin{array}{l}\text { Con } \\
100\end{array}$ & $\begin{array}{r}\text { Basz } \\
\text { entra } \\
200\end{array}$ & $\begin{array}{l}1 \text { sten } \\
\text { tion } \\
400\end{array}$ & $(\mathrm{ppm})$ & $\begin{array}{l}\text { Con } \\
100\end{array}$ & $\begin{array}{r}F \\
200 \\
20\end{array}$ & $\begin{array}{l}\text { iar } \\
\text { ion } \\
400\end{array}$ & ppm) & $\begin{array}{l}\text { Basal } \\
\text { stem }\end{array}$ & Foliar \\
\hline Control & 0 & & & & & & & & & & \\
\hline A-BR & & 2 & 2 & 1 & 1 & 0 & 0 & 0 & 4 & 30 & 20 \\
\hline A-s & & 1 & 3 & 5 & 5 & 0 & 0 & 0 & 3 & 70 & 15 \\
\hline C-mh & & 5 & 4 & 5 & 5 & 0 & 0 & 0 & 0 & 95 & 0 \\
\hline $\mathrm{C}-\mathrm{a}$ & & 4 & 3 & 5 & 5 & 0 & 0 & 0 & 0 & 85 & 0 \\
\hline C-aa & & 2 & 2 & 4 & 4 & 1 & 0 & 0 & 0 & 60 & 5 \\
\hline C-o & & 2 & 4 & 1 & 5 & 0 & 0 & 0 & 0 & 60 & $\mathbf{0}$ \\
\hline C-sc & 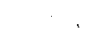 & 2 & 2 & 1 & 4 & 0 & 0 & 0 & 0 & 45 & 0 \\
\hline C-tsc & & 0 & 0 & 0 & 0 & 1 & 0 & 0 & 0 & 0 & 5 \\
\hline $\mathrm{Ph}-\mathrm{ac}{ }^{1}$ & & 0 & 0 & 0 & & 0 & 0 & 0 & & 0 & 0 \\
\hline Percentage & & & & & & & & & & & \\
\hline mortality & 0 & 40 & 44 & 49 & 73 & 4 & 0 & 0 & 18 & 51 & 5 \\
\hline
\end{tabular}

${ }^{\mathrm{I}}$ Not applied at $800 \mathrm{ppm}$.

numbers of trees, show that basal stem sprays resulted in the death of over 50 per cent of trees so treated. The data show, in general, an increase in mortality related to an increase in concentration. Trees varied in their response to spray materials as indicated by heavier mortality following the application of the lower concentrations as in the cases of Actidione BR concentrate (A-BR) and cycloheximide oxime (C-o) as basal stem sprays.

Needle loss values (Table 3), on the other hand show that foliar sprays rather than basal stem sprays caused damage. Calculations of the standard errors of each mean show that only in cycloheximide methyl hydrazone (C-mh) and cycloheximide thiosemicarbazone (C-tsc) applied to the foliage did confidence limits overlap with those of the control trees. The basal stem sprays gave only three instances where confidence limits did not overlap the control value.

Except where tree mortality rendered needle counts impossible, the data for infected needles (Table 4) show that substantial reductions in infection level were achieved. Values for the foliar sprays suggest a higher degree of 
TABLE 3

The Effect Of Spray Materials On Needle Retention

\begin{tabular}{|c|c|c|c|c|c|c|c|c|c|}
\hline \multirow[b]{2}{*}{$\begin{array}{c}\text { Spray } \\
\text { material }\end{array}$} & \multicolumn{9}{|c|}{ Percentage of needles missing 1} \\
\hline & $\begin{array}{l}\text { Conc } \\
\text { (ppm) } \\
0\end{array}$ & \multicolumn{4}{|c|}{$\begin{array}{l}\text { Basal stem apray } \\
\text { Concentration (ppm) }\end{array}$} & \multicolumn{4}{|c|}{$\begin{array}{c}\text { Foliar spray } \\
\text { Concentration (ppm) }\end{array}$} \\
\hline Control & $6 \pm 1$ & & & & & & & & \\
\hline A-BR & & 6 & 10 & 6 & 8 & 31 & 51 & 41 & 93 \\
\hline A-s & & 8 & 6 & -2 & - & 47 & 39 & 79 & 68 \\
\hline C-mh & & - & 10 & - & - & 9 & 7 & 8 & 7 \\
\hline $\mathrm{C}-\mathrm{a}$ & & 4 & 8 & - & - & 11 & 13 & 9 & 8 \\
\hline C-ana & & 6 & 5 & 2 & 15 & 32 & 5 & 11 & 16 \\
\hline C-o & & 5 & 6 & 9 & - & 16 & 13 & 11 & 7 \\
\hline C-sc & & 6 & 6 & 8 & 4 & 21 & 17 & 12 & 7 \\
\hline C-tsc & & 7 & 7 & 7 & 9 & 9 & 4 & 9 & 6 \\
\hline $\mathrm{Ph}-\mathrm{ac}^{3}$ & & 6 & 6 & 9 & & 11 & 5 & 9 & \\
\hline
\end{tabular}

${ }^{2}$ Percentage based on entire needle complement in samples.

'Dashes signify death of complete set of 5 trees.

${ }^{8}$ Not applied at $800 \mathrm{ppm}$.

TABLE 4

The Effect Of Spray Materials ON The Incidence Of Needle-Cast

\begin{tabular}{|c|c|c|c|c|c|c|c|c|c|}
\hline \multirow{3}{*}{$\begin{array}{c}\text { Spray } \\
\text { material }\end{array}$} & \multicolumn{9}{|c|}{ Percentage of needles infected ${ }^{2}$} \\
\hline & \multirow{2}{*}{$\begin{array}{l}\text { Conc. } \\
\text { (ppmin) } \\
0\end{array}$} & \multicolumn{4}{|c|}{$\begin{array}{c}\text { Basal stem spray } \\
\text { Concentration (ppm) }\end{array}$} & \multicolumn{4}{|c|}{$\begin{array}{c}\text { Foliar spray } \\
\text { Concentration (ppm) }\end{array}$} \\
\hline & & 100 & & $400^{\circ}$ & 800 & 100 & 200 & 400 & 800 \\
\hline \multicolumn{10}{|c|}{ Control $34 \pm 2$} \\
\hline A-BR & & 11 & 7 & 9 & 11 & 0 & 1 & 0 & 0 \\
\hline A-s & & 7 & 1 & —2 & 一 & 2 & 0 & 0 & 0 \\
\hline C-mh & & - & 3 & 一 & - & 25 & 13 & 13 & 9 \\
\hline $\mathrm{C}-\mathrm{a}$ & & 0 & 1 & 一 & - & 2 & 5 & 5 & 8 \\
\hline C-aa & & 2 & 17 & 0 & 10 & 1 & 2 & 3 & 3 \\
\hline $\mathrm{C}-\mathrm{o}$ & & 5 & 0 & 1 & - & 6 & 9 & 3 & 1 \\
\hline C-sc & & 0 & 12 & 6 & 0 & 1 & 2 & 1 & 2 \\
\hline C-tsc & & 5 & 9 & 5 & 5 & 11 & 5 & 8 & 6 \\
\hline $\mathrm{Ph}-\mathrm{ac}^{3}$ & & 7 & 8 & 11 & & 9 & 7 & 8 & \\
\hline
\end{tabular}

${ }^{1}$ Percentage based on remaining needles in samples.

${ }^{2}$ Dashes signify death of complete set of 5 trees.

${ }^{8}$ Not applied at $800 \mathrm{ppm}$.

control, but in all concentrations individual trees failed to exhibit values less than that of control trees. The highest infection counts made were in the basal stem application of cycloheximide aceto-acetate $(\mathrm{C}-\mathrm{aa})$ and the foliar application of cycloheximide methyl hydrazone $(\mathrm{C}-\mathrm{mh})$. These means and their 
respective standard errors were $17 \pm 10$ and $25 \pm 11$ per cent. Comparison with the value given for the control trees shows that only the value of $25 \pm 11$ fell within the control limit of error. All other calculated standard errors were significantly below the control value.

Two of the compounds used demonstrated little phytotoxicity and at the same time provided control of the disease. These materials were cycloheximide thiosemicarbazone (C-tsc) and Phyto-actin (Ph-ac).

The determination of Actidione content in the foliage of stem-treated trees (Figs. 1-6) shows translocation within 16 days in the trees sampled. Figs. $1-5$ represent the bioassay of treated tree foliage extract, and Fig. 6 is the assay of foliage from an untreated tree. In all figures the direction of solvent flow on the chromatogram prior to bioassay is from right to left, and the extract spotting is such that the path of the upper foliage extract is at the top and that of the Actidione standard is at the bottom. The presence of the standard can be seen in all figures. Corresponding dark zones of inhibition for upper and middle foliage can be seen in Fig. 5, the bioassay of the sixteenth-day sample. A slight inhibition zone is noticeable in Fig. 1 for the upper foliage of the tree sampled on the first day after spraying.

An inhibition zone is present at the left of Figs. 3-6 and presumably results from a substance other than Actidione in the extracts. The presence of the artifact prevented a quantitative evaluation of Actidione content in the samples.

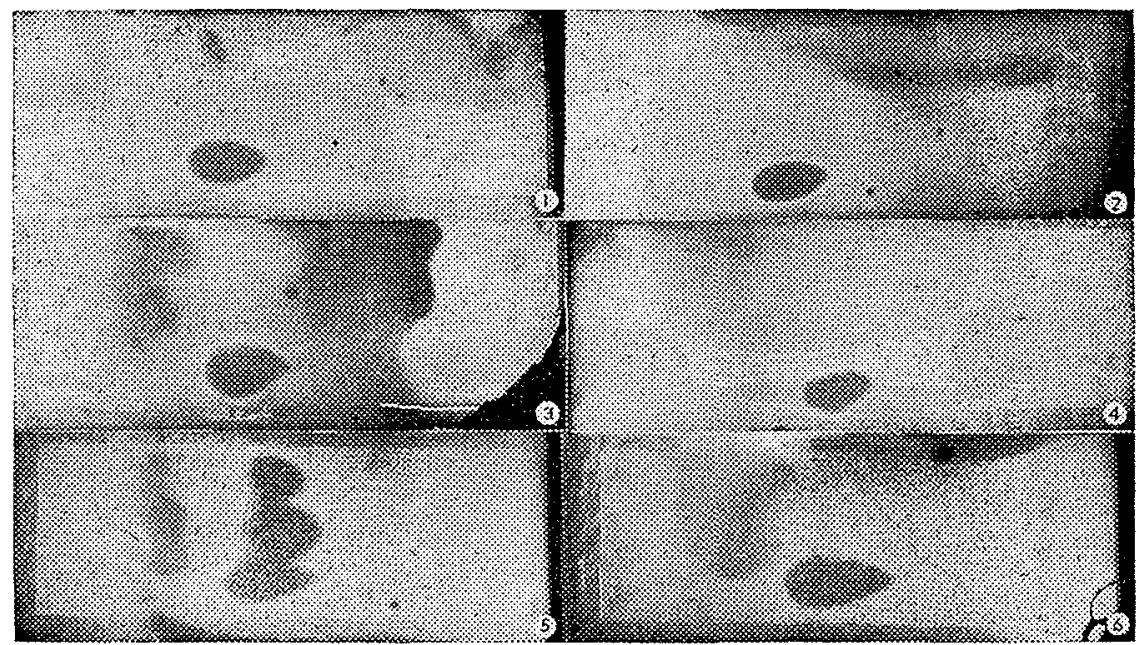

Results of detection tests for Actidione in foliage extracts. Figs. 1, 2, 3, 4, and 5 represent bioassays of samples taken from the middle and upper foliage of trees on the first, second, fourth, eighth, and sixteenth days respectively after spraying. Fig. 6 represents an identical bioassay carried out on an untreated tree. The presence of Actidione in the foliage can be seen, in Fig. 5, as dark zones which correspond to the position of the Actidione standard common to all figures. A faint zone of inhibition from Actidione can be seen in Fig. 1 in the upper foliage (top) position. Figs. 3, 4, 5, and 6 show the zone of inhibition caused by an artifact from the folizge itself. 


\section{Discussion}

The data collected in this preliminary evaluation of the efficacy of systemic antibiotics in the treatment of needle-cast of Douglas fir indicate that at least temporary control is possible. However, several questions arise out of the experiment that suggest the need for further study. These questions relate to two distinct problems with respect to differences in phytotoxic reactions in treated trees, both with materials and with concentrations of these materials as applied by the basal stem method. The first problem is a matter of determining the relationship between amounts applied and amounts that become available for translocation. Such a determination would depend upon the selection of an adequate bioassay organism for the materials used, as well as upon the correlation between bark thickness and penetration rate.

Coupled with the first problem is the variability of upward translocation, shown by Hendrickson and Vité (2) to be different, both in rate and pattern between adjacent Douglas fir trees. Even if the amount of spray, bark thicknesses, and bole diameters could be held constant between trees, it would not necessarily. follow that equal amounts of active ingredients would reach the foliage. The combination of a rapid rate of penetration and a slow rate of translocation might well provide for toxic accumulation of material in the cambial area resulting in tree death.

It seems likely, in view of the foliar spray data, that tree death following application of $100 \mathrm{ppm}$ of certain of the Actidione derivatives did not result entirely from the spray materials. While none of the control trees died the possibility of death resulting from a combination of spray material and the debilitating effect of successive defoliations must be considered.

Further experimentation is needed to confirm a hypothesis, arising from the data, that the minimum concentration necessary for control was exceeded at $100 \mathrm{ppm}$. It is possible that a decrease in concentration would establish effective control without heavy mortality and needle loss.

\section{ACKNOWLEDGMENT}

Grateful recognition is given to Dr. H. S. McNabb, Jr., who supervised the study, and to faculty members in the Department of Botany and Plant Pathology, Iowa State University, Ames, Iowa, for their helpful advice. The assistance and criticism offered by Dr. R. E. Foster and the staff of the Forest Entomology and Pathology Laboratory in Victoria, British Columbia, is greatly appreciated, as is the technical support given by The Upjohn Company, Kalamazoo, Michigan. 


\section{Literature Cited}

${ }^{2}$ BRANDT, R. W. 1960. The Rhabdocline needle cast of Douglas fir. Syracuse University. N.Y. State Coll. Forestry Tech. Bull. 84.

${ }^{2}$ HENDRICKSON, W. H. and J. P. VITÉ. 1960. The patterns of water conduction and tracheidal alignment in Douglas fir. Contrib. Boyce Thompson Inst. 20(6):353-362.

'LEMIN, A. J., WM. KLOMPARENS, and V. D. MOSS. 1960. The translocation and persistence of cycloheximide (Actidione) in white pine. For. Science $6(4): 306-314$.

${ }^{4}$ MOSS, V. D. 1958. Actidione stove oil treatment of blister rust cankers on reproduction and pole western white pine. Plant Disease Rept. 42(5): 703-706.

${ }^{5}$ MOSS, V. D., T. R. PETERSON, and W. E. BOUSFIELD. 1961. Antibiotic development and improvement work. U.S. Dept. Agric. Forest Serv. Regional Annual Blister Rust Control Report 1960: 38-49.

${ }^{\circ}$ VLOTEN, H. van. 1932. Rhabdocline psezdotsugae Sydow, corsaack eener ziekle van Douglasspar. (Wageningen) Landbouwhoogesch, Proefschrift. (Summarized in Rev. Appl. Mycology 12(1): 63-64.)

${ }^{7}$ WEIR, J. R. 1917. A needle blight of Douglas fir. J. Agr. Res. 10(2): 99-103.

${ }^{9}$ WEIR, L. C. 1961. Control of needle cast disease of Douglas fir with systemic chemicals. Unpublished thesis. Iowa State University library, Ames, Iowa.

${ }^{\circ}$ WHIFFEN, A. J. 1948. The production, assay, and antibiotic activity of Actidione, an antibiotic from Streptomyces griseus. J. Bact. 56(3): 283-291.

${ }^{10}$ WICKER, E. F., and C. D. LEAPHART. 1962. Effects of three antibiotics on tree diseases and forest vegetation following aerial applications to western white pine stands. Plant Disease Reptr. 45(9): 722-724.

${ }^{11}$ WILSON, M. 1927. Defoliation of the Douglas fir. Gard. Chron. No. 2106: 323-324. 